\title{
SPATIAL VARIABILITY OF SOIL ACIDITY ATTRIBUTES AND THE SPATIALIZATION OF LIMING REQUIREMENT FOR CORN
}

\author{
Variabilidade espacial de atributos de acidez do solo e \\ espacialização da necessidade de calagem para o milho
}

\author{
Sandro Manuel Carmelino Hurtado ${ }^{1}$, Carlos Alberto Silva ${ }^{2}$, Álvaro Vilela de Resende ${ }^{3}$, \\ Renzo Garcia Von Pinho ${ }^{4}$, Euzelina dos Santos Borges Inácio ${ }^{5}$, Fábio Satoshi Higashikawa ${ }^{6}$
}

\begin{abstract}
In Brazil, technicians, in most cases, ignore the aspects related to the spatial variability of the soil acidity attributes when liming requirement is calculated. The objective of this study was to validate the liming practice, evaluating the presence of spatial variability of the soil acidity attributes and the existence of areas with differentiated liming requirement, which were calculated by different methods. The experiment was carried out in an area cultivated with corn under conventional management and irrigation. The soil (0-0.2 m) was sampled in a conventional way (composite soil sample) and in a systematic scheme, by use of a grid sampling. In sequence to the soil fertility attributes analysis, it was calculated the liming requirement, according to the methods of SMP $\mathrm{pH}$, aluminum neutralization and elevation of soil $\mathrm{Ca}$ and $\mathrm{Mg}$ levels, and increase of the soil base saturation. After the descriptive analysis of the data set was accomplished, the semivariograms were calculated and the maps were obtained through the kriging technique. Absence of spatial dependence, as well as the non necessity of limestone application, was observed for the Al neutralization calculation method. Spatial dependence was only verified for the soil acidity attributes and to the liming requirement calculated by the base saturation and SMP pH methods; for these two methods, the semivariogram ranges obtained varied from 35.7 to $200.5 \mathrm{~m}$. The results have highlighted the existence of differentiated liming requirement zones when the variability of the soil acidity attributes was considered in the calculation of the dose and type of limestone to be used for corn soil acidity correction.
\end{abstract}

Index terms: Precision agriculture, geostatistics, Zea mays (L), liming application zones.

\section{RESUMO}

No Brasil, a prática de calagem desconsidera, na maioria das vezes, os aspectos relacionados à variabilidade espacial dos atributos de acidez do solo. Objetivou-se, neste estudo, validar a prática da calagem, avaliando a presença de variabilidade espacial de atributos de acidez do solo e a existência de áreas com necessidades diferenciadas de corretivo, por meio de diferentes métodos de cálculo da necessidade de calagem. O experimento foi realizado em lavoura de milho sob manejo convencional. O solo foi amostrado de forma convencional (amostra composta) e sistemática (mediante uso de grade amostral), na profundidade de 0-0,2 m. Posteriormente à análise de fertilidade de rotina, determinaram-se as necessidades de calagem segundo os métodos do tampão SMP, da neutralização de alumínio e elevação do $\mathrm{Ca}$ e $\mathrm{Mg}$, e da saturação por bases. Após análise descritiva, foram obtidos os semivariogramas e os mapas por krigagem. Ausência de dependência espacial, assim como da necessidade de aplicação do corretivo calcário foram observadas para o método da neutralização de Al. A dependência espacial foi encontrada para os atributos de acidez do solo e para as necessidades de calagem calculadas pelos métodos de saturação por bases e pH SMP, com alcances variando entre 35,7 e 200,5 m. Esses últimos mostraram também, uma coincidência regionalizada entre as maiores demandas de calcário. Os resultados permitiram evidenciar a existência de zonas de aplicação de calcário diferenciadas, quando consideradas a variabilidade dos atributos de acidez do solo no cálculo espacializado da dose e o tipo de corretivo calcário a ser utilizado.

Termos para indexação: Agricultura de precisão, geoestatística, Zea mays L., zonas de aplicação de calcário.

(Received in october 15, 2007 and approved in June 25, 2008)

\section{INTRODUCTION}

The acidity in Brazilian soils represents a strongly limiting factor for increasing crop yield. In acid soils, the toxicity caused by $\mathrm{Al}^{3+}$ and/or $\mathrm{Mn}^{2+}$ or the low levels of $\mathrm{Ca}^{2+}$ and
$\mathrm{Mg}^{2+}$ restrict root growth (ROSSIELLO JUNQUEIRA \& NETTO, 2006; PADUA et al., 2008), the availability of nutrients (MALAVOLTA et al., 1997), and the biological activity (MOREIRA $\&$ SIQUEIRA, 2006), impairing growth and development of plants. Thus, liming is an essential practice to obtain high yields.

'Doctor. Soil Science Undergraduation Program, financed by CAPES - IEL National - Brazil, Federal University of Lavras. Lavras, MG, CEP 37200-000. sandroelbat@yahoo.com.br

2Professor Doctor. Soil Science Department, Federal University of lavras. Lavras, MG, CEP 37200-000. csilva@ufla.br

${ }^{3}$ Researcher. Embrapa Maize and Sorghum. Rod. MG 424, Km 45, Box 285, CEP 35701-970, Sete Lagoas, MG. E-mail: alvaro@cnpms.embrapa.br.

${ }^{4}$ Professor Doctor. Agriculture Department, Federal University of Lavras. Lavras, MG, CEP 37200-000. renzo@ufla.br

${ }^{5}$ Doctor, Federal University of Lavras. Lavras, MG, CEP 37200-000. euzi_inacio@yahoo.com.br

${ }^{6}$ Master's student, Soil Science Undergraduation Program. Federal University of Lavras. Lavras, MG, CEP 37200-000. rioloste@gmail.com 
In many agricultural regions, liming is a common and well established practice, both in conventional and conservation production systems. However, there is a common large spatial variability of the conditions of soil acidity, even in apparently homogeneous crop areas. According to Pierce \& Novak (1999), in the calculation of the lime requirement, besides considering the soil buffer capacity and crop tolerance to soil acidity, it is also necessary to take into account the variability of the soil acidity attributes. Otherwise, it is great the chance to have over liming in some parts of the land and use of limestone sub doses in other parts of the field. Thus, the strategy for soil sampling has an important role in defining the amount of lime to be applied. Application of sub doses of lime limits the expression of crop yield potential by not satisfactorily correct the soil acidity according to the crop needs. Moreover, the application of lime in excess can lead to chemical or physical problems, such as micronutrient deficiency, and clay dispersion, influencing the aggregation of soil particles and changing the porous system, with consequences in soil mechanical and erosion processes (LACERDA et al., 2006). Therefore, the management of acid soils is related not only to the right definition of lime quantity but also to the efficiency in the allocation of the limestone in the different part of the crop area. Thus, there is a need to adapt the methods of determining the lime requirement in order to consider the spatial variability of soil acidity attributes, preferably using the site-specific management techniques or precision agriculture tools.

In Brazil, there is a range of methods used for calculating the lime requirement, with emphasis on three methods: i) SMP buffer (Shoemaker et al., 1961), which is based on raising the $\mathrm{pH}$ to desired values; ii) the method of $\mathrm{Al}$ neutralization and elevation the soil $\mathrm{Ca}$ and $\mathrm{Mg}$ levels (CFSEMG 1999), which has as a goal to neutralize the $\mathrm{Al}$ toxicity to plants and increase the availability of $\mathrm{Ca}$ and $\mathrm{Mg}$, according to the tolerance of crops to $\mathrm{Al}$ and its requirements in exchangeable bases; and iii) the method based on elevating the base saturation for pre-determined values, according to the crop requirement (RAIJ, 1991).

In most cases, however, the limestone recommendation is based on conventional soil sampling, where a single composite sample is collected in order to represent areas of ten hectares or more, supposedly homogeneous. Thus, the crops areas are treated uniformly by average conditions of acidity in different points, without considering the aspects of soil attributes spatial variability (SILVEIRA et al., 2000; SOUZA et al., 1997, 2004; VIEIRA \& PAZ-GONZALEZ, 2003; SOUZA et al., 2007; VIEIRA et al.; 2007). In fact, the values of soil $\mathrm{pH}$ are dependent on the soil sampling location, with records of differences in $\mathrm{pH}$ values of about 2 to 3.1 units, with strong spatial dependence (PIERCE et al., 1995). The accuracy in the soil acidity correction is an important factor to increase the crop yield, to raise the efficiency of use of a range of agricultural inputs, and to improve different soil natural processes. Thus, the study of patterns of the soil acidity attributes variability is justified, as well as the calculation of liming requirement by different methods, considering the soil acidity spatial variability. The objective of this study was to validate the liming practice, in a conventional way, by evaluating the presence of spatial variability of soil acidity attributes and the possible existence of areas with different limestone requirements which were, determined by different methods of calculation, considering the use of precision agriculture tools.

\section{MATERIALS AND METHODS}

The study was based on the data obtained by the analysis of soil samples collected in an experimental area of the Federal University of Lavras, MG, in agricultural year of 2005-2006. The area of $0.72 \mathrm{ha}(360 \mathrm{~m} \mathrm{x} 20 \mathrm{~m})$ is located at the latitude $21^{\circ} 13$ ' $24^{\prime \prime}$ South and longitude of $44^{\circ} 58^{\prime} 43^{\prime \prime}$ 'West, with average altitude of $900 \mathrm{~m}$. The soil, classified as a Red Latossol (Oxisol), has a clay content equal to $488 \mathrm{~g} \mathrm{~kg}^{-1}$ and has been cultivated with corn under conventional tillage and irrigation since 12 years ago. Before the corn sowing, in September 2005, $2 \mathrm{t} \mathrm{ha}^{-1}$ of limestone were applied in the crop area sampled, in order to increase the soil base saturation to $60 \%$ (RAIJ, 1991). Soil acidity correction described before was based on the soil sampling in a conventional way (20 simple subsamples, randomly collected, to form a composite soil sample).

After the limestone reaction (three months after the liming practice), two types of soil sampling were performed, both in the soil layer of $0-0.2 \mathrm{~m}$ : i) conventional sampling was done through a simple collection of 20 subsamples, randomly in the area, to form a composite sample, which was analyzed in the laboratory; ii) in a spatialized scheme, five simple subsamples were collected to represent each of the 63 sampling points located at the intersections of a regular grid of $18 \mathrm{~m} \mathrm{x} 9 \mathrm{~m}$. The sampling grid was conceived in order to obtain a sufficient number of soil samples required for geostatistical analysis. The samples were subjected to routine chemical and physical (texture) analysis, according to the methods described in Embrapa (1999). It was calculated the values of the effective CEC, $\mathrm{CEC}$ at $\mathrm{pH} 7.0$, sum of bases, base saturation, calcium saturation, magnesium saturation and the $\mathrm{Ca}^{2+} / \mathrm{Mg}^{2+}$ ratio.

Based on the analytical results of the two soil sampling schem accomplished, and to validate the liming 
practice undertaken by the conventional method, it was determined, again, the lime requirements (LR) for corn, using different methods of calculation, in order to elevate the base saturation to 50\% (CFSEMG, 1999) and 60\% (RAIJ, 1991), and to obtain a $\mathrm{pH}$ in water equal to 6.0, when the SMP buffer method was used (Shoemaker et al., 1961), and to neutralize $\mathrm{Al}$ and to increase the levels of $\mathrm{Ca}$ and $\mathrm{Mg}$ in soil (CFSEMG, 1999).

The soil data set and the LR were analyzed by descriptive and spatial statistics techniques. In the descriptive statistics approach, data were analyzed in order to obtain the minimum and maximum values, average, median, and the coefficients of variation and of skewness and the kurtosis, using the software SISVAR (FERREIRA, 2004). In the spatial analysis approach, using the geostatistics concepts, the spatial dependence was determined by calculating the semivariance (equation 1), assuming the stationarity of the intrinsic hypothesis (VIEIRA et al., 1983).

$$
\gamma(h)=\frac{1}{2 N(h)} \sum_{i=1}^{N}\left[Z\left(x_{i}\right)-Z\left(x_{i}+h\right)\right]^{2}
$$

where $\mathrm{N}(\mathrm{h})$ is the number of pairs of $\mathrm{Z}\left(\mathrm{x}_{\mathrm{i}}\right)$ and $\mathrm{Z}\left(\mathrm{x}_{\mathrm{i}}+\mathrm{h}\right)$ values separated by the $\mathrm{h}$ distance.

The use of equation 1 denotes discrete values for the distances of the semivariances, making necessary the adjustment of the mathematical models well order to have semivariances to a continuous dominion (VIEIRA \& PAZGONZALEZ, 2003). After the calculation of the semivariograms, it was performed the adjustment of the models, in order to estimate the nugget effect (Co), contribution (C) and the range (a) for each semivariogram. Spherical, gaussian and exponential models were fitted in all cases (CRESSIE, 1991). Selection of models for semivariograms was based on visual fit, with subsequent use of auto validation analysis (Vieira, 2000). The degree of spatial dependence (GD), which determines the relationship between spatial variance and the total variance, reflected by the ratio of nugget to total semivariance, was considered strong for values lower than $25 \%$, moderate, for values between 25 and $75 \%$, and weak, for values higher than $75 \%$ (CAMBARDELLA et al., 1994).

In case of spatial dependence, the variables values were interpolated by ordinary kriging using the parameters of the semivariogram models fitted, with the aid of the geoR software (RIBEIRO JÚNIOR \& DIGGLE, 2001). Semivariogram was calculated considering the isotropy of the data set. Surface maps were confectioned for the attributes analyzed.

\section{RESULTS AND DISCUSSION}

\section{Descriptive statistical analysis}

The descriptive statistics for the LR data determined by different criteria and for the soil acidity attributes is shown in the Table 1. The data generated from spatializated soil sampling showed symmetrical distribution for most of the attributes measured, which is evidenced by the similar values of mean and median. The symmetry of the data is confirmed also by the coefficients of skewness and kurtosis near zero and three, respectively, indicating data with normal distribution, which allows the optimization of the estimates by kriging (CARVALHO et al., 2002).

According to Souza et al. (2004), the presence of extended tails is very undesirable since they interfere in the kriging interpolation, which are based on average values. Strong tails found for de LR calculated by the Al and $\mathrm{Ca}+\mathrm{Mg}$ criterion may be associated with high coefficients of skewness and kurtosis, which are related to the proximity of the minimum to the mean and median values; the few maximum values found are responsible for the heavy tails occurrence.

An idea of the variation of the data may be provided by the amplitude of the values. Thus, it must be highlighted the importance of linking the average values with the minimum and maximum points, alerting to the possibility of sub or super doses of lime; extreme values that could find themselves concentrated in certain locations of the field is not perceived in descriptive analysis, either in conventional sampling. Among the attributes of soil acidity evaluated, it was observed that the $\mathrm{pH}$ ranged from 5.0 to 6.4, which is the interval that could be classified (CFSEMG, 1999), according to its spatial position, from low to high levels. The potential acidity, in turn, varied from 1.5 to 4.5 $\mathrm{cmol}_{\mathrm{c}} \mathrm{dm}^{-3}$, values belonging to the fertility classes of low or medium levels. The $\mathrm{CEC}$ at $\mathrm{pH} 7$ ranged from 4.7 to 7.7 $\mathrm{cmol}_{\mathrm{c}} \mathrm{dm}^{-3}$, oscillating between the limits of the levels considered as medium (Table 1 ).

In this study, the values of the attributes related to soil acidity obtained by conventional sampling falls in the interval considered as medium (CFSEMG 1999), with little variation (less than 9\%) from the average of the systematic sampling, where the attributes are also classified as medium values. Contrary situation was observed for the estimates of LR (Table 1), which is related to the different coefficient of variation values found for this attribute. This fact is explained because of the spatial variability of soil attributes 
Table 1 - Descriptive statistics for the soil attributes and lime requirement (LR) data derived from spacitialized and conventional soil sampling.

\begin{tabular}{|c|c|c|c|c|c|c|c|c|}
\hline \multirow{3}{*}{ Attributes } & \multicolumn{7}{|c|}{ Spacitialized sampling } & \multirow{3}{*}{$\begin{array}{c}\text { Conventional } \\
\text { sampling }\end{array}$} \\
\hline & \multicolumn{2}{|c|}{ Value } & \multirow[b]{2}{*}{ median } & \multirow[b]{2}{*}{ mean } & \multirow[b]{2}{*}{$\mathrm{CV}^{1}$} & \multicolumn{2}{|c|}{ Coefficient $^{2}$} & \\
\hline & minimum & maximum & & & & skewness & kurtosis & \\
\hline $\mathrm{pH}$ in water & 5.0 & 6.4 & 5.5 & 5.6 & 6.2 & -0.41 & 5.39 & 5.9 \\
\hline Calcium $\left(\mathrm{cmol}_{\mathrm{c}} \mathrm{dm}^{-3}\right)$ & 0.9 & 3.0 & 1.8 & 1.7 & 26.3 & 0.58 & 3.13 & 1.8 \\
\hline Magnesium $\left(\mathrm{cmol}_{\mathrm{c}} \mathrm{dm}^{-3}\right)$ & 0.3 & 1.7 & 1.0 & 1.0 & 28.4 & 0.06 & 2.99 & 1.2 \\
\hline Potash (mg dry matter ${ }^{-3}$ ) & 36.0 & 156.0 & 99.1 & 96.0 & 30.7 & 0.10 & 2.39 & 80.0 \\
\hline Aluminum $\left(\mathrm{cmol}_{\mathrm{c}} \mathrm{dm}^{-3}\right)$ & 0.0 & 0.3 & 0.1 & 0.0 & 134.4 & 0.72 & 1.72 & 0.0 \\
\hline $\mathrm{H}+\mathrm{Al}\left(\mathrm{cmol}_{\mathrm{c}} \mathrm{dm}^{-3}\right)$ & 1.5 & 4.5 & 2.8 & 2.6 & 27.1 & 0.69 & 2.75 & 2.3 \\
\hline $\mathrm{CEC}$ at $\mathrm{pH} 7\left(\mathrm{cmol}_{\mathrm{c}} \mathrm{dm}^{-3}\right)$ & 4.7 & 7.7 & 5.9 & 5.8 & 12.9 & 0.89 & 2.93 & 5.5 \\
\hline Base saturation (V) (\%) & 24.8 & 72.9 & 52.1 & 51.2 & 19.1 & 0.03 & 2.85 & 58.2 \\
\hline Ca saturation $(\%)$ & 12.0 & 48.0 & 31.1 & 31.0 & 26.9 & 0.00 & 2.39 & 32.7 \\
\hline $\mathrm{Mg}$ saturation (\%) & 9.0 & 29.0 & 17.1 & 18.0 & 26.8 & 0.17 & 2.67 & 21.8 \\
\hline $\mathrm{Ca}: \mathrm{Mg}$ ratio & 0.8 & 3.2 & 1.8 & 1.9 & 32.4 & 0.39 & 2.66 & 1.5 \\
\hline $\mathrm{V}_{50 \%} \mathrm{LR}\left(\mathrm{t} \mathrm{ha}^{-1}\right)$ & 0.0 & 1.6 & 0.5 & 0.5 & 61.1 & 0.50 & 2.09 & 0.10 \\
\hline $\mathrm{V}_{60 \%} \mathrm{LR}\left(\mathrm{t} \mathrm{ha}^{-1}\right)$ & 0.0 & 2.4 & 1.1 & 1.0 & 58.7 & 0.28 & 2.32 & 0.65 \\
\hline $\operatorname{SMP} \operatorname{LR}\left(\mathrm{t} \mathrm{ha}^{-1}\right)$ & 0.0 & 2.3 & 0.9 & 1.2 & 76.6 & 0.25 & 1.78 & 0.58 \\
\hline $\mathrm{Al} \& \mathrm{Ca}+\mathrm{Mg} \mathrm{LR}\left(\mathrm{tha}^{-1}\right)$ & 0.0 & 0.4 & 0.01 & 0.0 & 646.8 & 7.08 & 53.24 & 0.0 \\
\hline
\end{tabular}

${ }^{1} \mathrm{CV}$ : Coefficient of variation (\%); ${ }^{2}$ Values provided when used the beta estimation.

used for LR calculations, which changed the demand of lime for the different parts of the crop field.

The levels of calcium and magnesium saturation were in the range from $12 \%$ to $48 \%$ and $9 \%$ to $29 \%$, respectively. Although the $\mathrm{Ca}: \mathrm{Mg}$ ratio is located in the range of $2: 1$, relations above of that value can be found in soils cultivated with corn; in fact, the ideal $\mathrm{Ca}: \mathrm{Mg}$ recommended for soil where corn is grown is around 3:1 (VITTI et al., 2003). In comparison with the data showed before, $\mathrm{Ca}: \mathrm{Mg}$ ratio decreased (1.5:1), when conventional sampling was performed. Thus, conventional sampling and/ or use of average values originated form systematic sampling may not adequately represent the variation of the data in the field, as it was observed by Carvalho et al. (2002).

The lime requirements ranged from 0 to $2.4 \mathrm{t} \mathrm{ha}^{-1}$ and they were regulated by the sampling method and type of estimation (Table 1). There are also differences in the recommendations made with the use of $\mathrm{Al}$ and $\mathrm{Ca}+\mathrm{Mg}$ method in comparison to the methods based on the increase of base saturation and soil pH (SMP method).

No necessity for liming verified for the $\mathrm{Al}$ neutralization and supply of $\mathrm{Ca}$ and $\mathrm{Mg}$ method could be explained by the low exchangeable acidity, less than the maximum permitted values for the cultivation of maize, as well as the sum of the contents of $\mathrm{Ca}$ and $\mathrm{Mg}$, which is higher than $2 \mathrm{cmol} \mathrm{dm}^{-3}$ (CFSEMG, 1999). The method based on the increase of base saturation indicates, in turn, the need for correction of soil acidity for corn when the levels of $\mathrm{V}$ are below $60 \%$, recommending the elevation to 70\% (RAIJ, 1991). According to CFSEMG (1999), applications of lime are recommended for $\mathrm{V}$ below $50 \%$. In this study, the levels of $\mathrm{V}$ ranged from $24.8 \%$ to $72.9 \%$, with an average of $52.1 \%$, according to sampling carried out by using soil grid. According to the estimates made using the $\mathrm{pH}$ SMP method, it was also recommended applications of lime in order to raise the $\mathrm{pH}$ in water to 6.0 (FURTINI NETO et al., 2001).

In this study, the lowest values of $\mathrm{CV}$ were observed for the soil pH. According to Wilding \& Drees (1983), cited by Corá et al. (2004), most of the attributes presented a moderate variation, $15<\mathrm{CV}<35 \%$, which is in agreement with the data presented by Silveira et al. (2000) and Souza et al. (2004), for the chemical attributes $\mathrm{Ca}, \mathrm{Mg}$ and $\mathrm{V}$, and Silva et al. (2003), for the levels of $\mathrm{K}$ in soil. Low values of $\mathrm{CV}$, i.g. $\mathrm{CV}<15 \%$, were observed for the $\mathrm{pH}$ and $\mathrm{CEC}$ at $\mathrm{pH}$ 7 , agreeing with Corá et al. (2004). High values of CV (> $35 \%$ ) for Al were reported by Silva et al. (2003). In this study, high CV was also observed for the LR and by the different estimation methods of limestone doses.

The highest values of $\mathrm{CV}$ observed for the $\mathrm{Al}$ levels and for the LR using the Al neutralization method can be explained by the proximity of the lower and the median values, where the presence of the maximum values shows a strong skewness in the tails of the data set distribution. 
Wollenhaupt et al. (1997) mentioned that, although it can be inferred the existence of variation in the data from the value of $\mathrm{CV}$, could not be considered in the spatial evaluation of the data, given the possibility of them tobe localized in specific regions of the field.

\section{Spatial statistical analysis}

The spatial analysis was performed for the LR calculation methods and for the soil acidity attributes, and the presence of spatial dependence was verified for most of the attributes evaluated (Table 2). Both the ratio $\mathrm{Ca}: \mathrm{Mg}$ as well as the LR calculated by using the Al neutralization method showed random spatial distribution, reflected in the pure nugget effect.

The semivariogram models adjusted for the soil attributes were the spherical, the exponential and the gaussian, whereas, for the LRs, the best adjusted model was the gaussian (Table 2). The attributes with the presence of spatial variation showed GD in the range of 43.7 to $57.3 \%$ (moderate), with the exception of the attribute CEC at pH 7, with $20.5 \%$ of GD, which is classified as strong (CAMBARDELLA et al., 1994).

The semivariograms ranges varied from $35.7 \mathrm{~m}$, for the $\mathrm{pH}$ values, to $200.5 \mathrm{~m}$, for the $\mathrm{Mg}$ saturation, and it was observed range values similar amongst the LR calculation methods. Range values become important for planning future sampling, allowing the conception of scale of grids and the estimation of the number of points to be sampled (SOUZA et al., 1997). For Mulla \& Mc Bratney (2000), regular grids with $1 / 4$ to $1 / 2$ of the value range are recommended. Carvalho et al. (2002) refer, in turn, to grids with cell size equal to twice the value of range to be used in conventional sampling, in order to maintain independence between the points, the minimization of error and reduction of the number of sampling points in future. It should be noted that $\mathrm{Ca}$ and $\mathrm{Mg}$ the saturation and the $\mathrm{Ca}: \mathrm{Mg}$ ratio are determined considering the soil $\mathrm{Ca}$ and $\mathrm{Mg}$ levels and the $\mathrm{CEC}$ at $\mathrm{pH}$ 7. Thus, the ranges of these attributes should be considered in future soil fertility surveys.

$\mathrm{Ca}$ and $\mathrm{Mg}$ the spatial behavior of $\mathrm{pH}$, base saturation, the saturation and the LR's obtained by different calculations methods, considering the presence of spatial dependence, are showed in Figure 1. The data set shows a regionalized coincidence between the levels of $\mathrm{pH}$ and the $\mathrm{V}$ values (Figures 1A and 1B), as well as between the levels of $\mathrm{pH}$ and the $\mathrm{Ca}$ and $\mathrm{Mg}$ saturation $\mathrm{Mg}$ (Figures $1 \mathrm{~A}, 1 \mathrm{C}$ and 1D), which is directly related to the availability of these nutrients as a function of $\mathrm{pH}$.

Even in places with higher levels of Ca saturation, in general, the levels of this attribute is presented in the soil below the optimal levels of 38-54\%, which are recommended for areas cultivated with corn (FANCELLI \& DOURADO NETO, 1997). According to these authors, ideals values of $\mathrm{Mg}$ saturation are in the range of $9-16 \%$, which were observed in this study, even in places with low levels of $\mathrm{Mg}$ in soil. The direct relationship found between the maps of $\mathrm{Ca}$ saturation and magnesium saturation explain the absence of spatial dependency for the Ca: $\mathrm{Mg}$ ratio.

Table 2 - Spatial statistics for $\mathrm{pH}$, available calcium and magnesium, base saturation, $\mathrm{CEC}$ at $\mathrm{pH} 7$, calcium saturation, magnesium saturation, $\mathrm{Ca}: \mathrm{Mg}$ ratio, and for lime requirements calculated by different methods, in a cultivated corn area.

\begin{tabular}{|c|c|c|c|c|c|}
\hline Attributes & Model & Nugget Effect (Co) & Contribution (C) & Range (a) & $\mathrm{GD}^{2}(\%)$ \\
\hline $\mathrm{pH}$ & Gaussian & 0.03 & 0.04 & 35.7 & 43.7 \\
\hline Calcium & Spherical & 0.11 & 0.09 & 43.2 & 53.7 \\
\hline Magnesium & Exponential & 0.05 & 0.04 & 56.7 & 55.8 \\
\hline $\mathrm{CEC}$ at $\mathrm{pH} 7$ & Gaussian & 0.19 & 0.72 & 117.9 & 20.5 \\
\hline Base saturation (V\%) & Spherical & 37.90 & 28.30 & 70.8 & 57.3 \\
\hline Ca saturation & Exponential & 21.97 & 27.31 & 64.8 & 55.4 \\
\hline Mg saturation & Exponential & 12.92 & 12.05 & 200.5 & 48.3 \\
\hline $\mathrm{Ca}: \mathrm{Mg}$ & PNE. ${ }^{1}$ & --- & --- & --- & --- \\
\hline \multicolumn{6}{|c|}{ Lime Requirements } \\
\hline $50 \% \mathrm{~V}$ & Gaussian & 0.09 & 0.08 & 86.5 & 47.1 \\
\hline $60 \% \mathrm{~V}$ & Gaussian & 0.14 & 0.18 & 118.2 & 56.2 \\
\hline pH SMP & Gaussian & 0.25 & 0.21 & 116.8 & 45.7 \\
\hline Al neutralization & PNE. & --- & --- & --- & --- \\
\hline
\end{tabular}

${ }^{1}$ PNE: pure nugget effect.

${ }^{2} \mathrm{GD}$, degree of spatial dependence: strong: $\mathrm{x}<25 \%$; moderate: $25 \%<\mathrm{x}<75 \%$; weak: $\mathrm{x}>75 \%$ (Cambardella et al., 1994). 
A

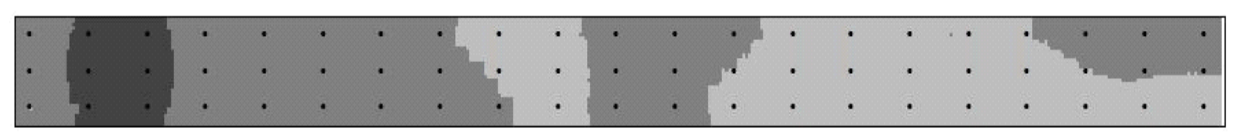

$\mathrm{pH}$

B

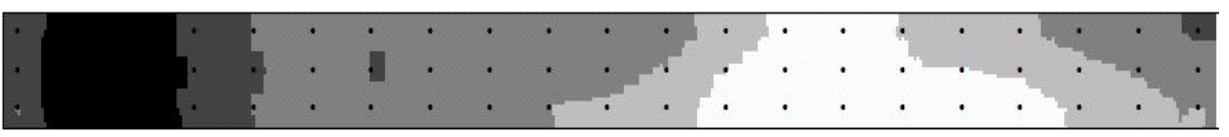

C

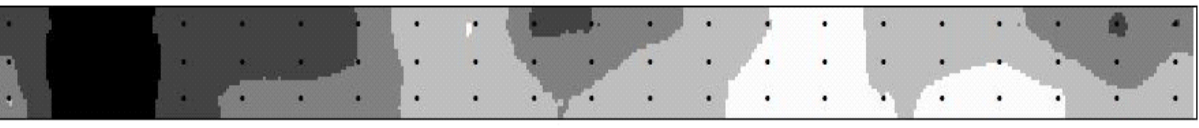

D.

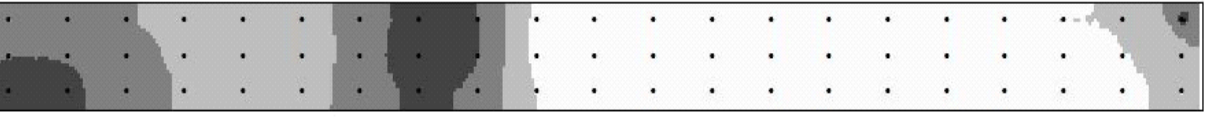

$<4.5$

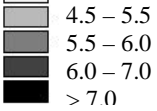

V (\%)

$\square<45$

$<45$

$50-55$
$55-60$

$55-60$
$>60$

$\% \mathrm{Ca}$

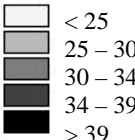

$\% \mathrm{Mg}$

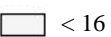

$\square<16$
$\square-16-18$

$16-18$
$18-20$

$18-20$
$20-22$

$>22$

E

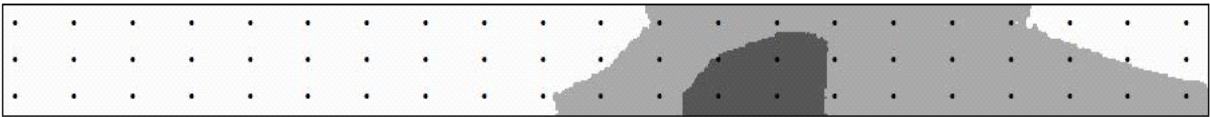

F
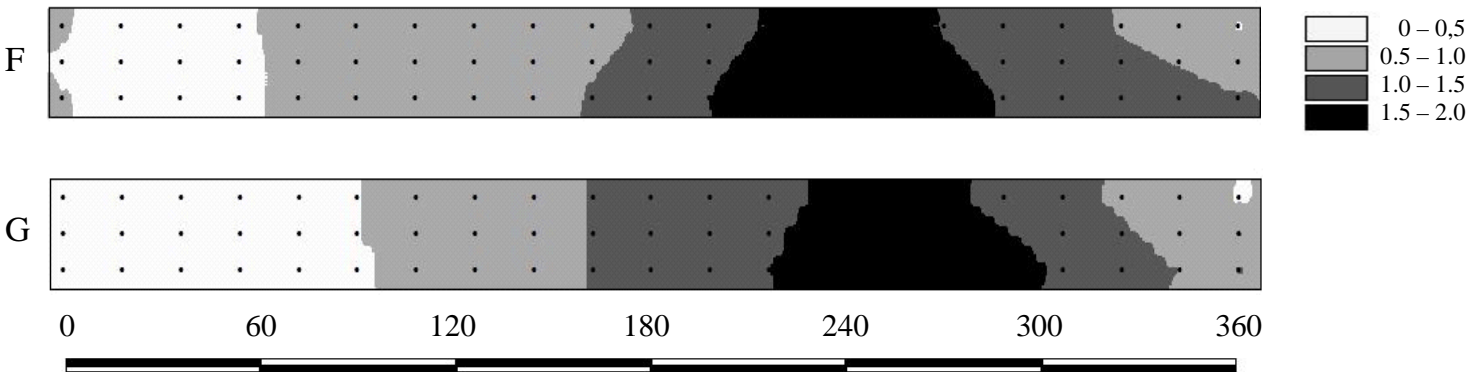

Distance $(\mathrm{m})$

Figure 1 - Kriging maps for $\mathrm{pH}(\mathrm{A})$, base saturation, V\% (B), Ca saturation, \% Ca (C), Mg saturation, \% Mg (D) attributes and for the lime requirements based on the elevation of base saturation to $50 \%$ (E) and to 60\% (F), and for the SMP pH (G) methods, in a cultivated corn area.

In general, lower LRs were observed in the left part of the maps, including the range of distances between 0 and $160 \mathrm{~m}$, in the direction of the axis of abscissa (Figures $1 \mathrm{E}, 1 \mathrm{~F}$ and $1 \mathrm{G})$. In this sense, and in a way less strict, this fact allows to divide the field into two main sub areas or lime application zones with LR specific for each calculation method, which facilitates and becomes more precise the management of soil acidity correction. According to Raij (1991), the greatest benefits of using the method based on elevation of base saturation is derived from its greater complexity, since its adoption allows to, indirectly, increase the levels in soil of $\mathrm{Ca}, \mathrm{Mg}$ and $\mathrm{K}$. For the maps based on the base saturation method, the LRs changed when applications were recommended to increase $\mathrm{V}$ to $50 \%$ or $60 \%$, according to the recommendations of CFSEMG (1999) and Raij (1991), respectively. It is also possible to see in the maps a coincidence for lime rate based on the elevation of base saturation to achieve $\mathrm{V}$ equal to $60 \%$ and $\mathrm{SMP} \mathrm{pH}$ (Figures $1 \mathrm{~F}$ and $1 \mathrm{G}$ ), showing sub areas with varying LR of $0-1 \mathrm{tha}^{-1}$ and $1-2 \mathrm{tha}^{-1}$ of lime.

It should be noted that the for the limestone requirement based on conventional sampling, it is not 
recommend the application of corrective for doses lower than $0.5 \mathrm{t} \mathrm{ha}^{-1}$, if the incorporation of limestone are not performed (FURTINI NETO et al., 2001). Thus, the application of the acidity corrective in the dose recommended by conventional sampling (Table 1) would result in sub doses of lime in the areas of highest demand for limestone. Inefficiency in the application of corrective associated to conventional soil sampling has been detected in some regions of the field due to the spatial variability of the soil attributes, changing the amounts of limestone recommended by the method of estimation used. Amongst the methods evaluated, the neutralization of the aluminum with increase of $\mathrm{Ca}$ and $\mathrm{Mg}$ levels was the calculation method which presented no need for soil corrective after the liming accomplishment before the corn sowing.

The maps of Figure 1 also showed the presence of two large areas for the levels of Ca saturation, and the sub areas with the lowest values $(\% \mathrm{Ca}<30 \%)$ coincided regionally to the areas with the highest $\mathrm{LR}\left(>1 \mathrm{t} \mathrm{ha}^{-1}\right)$. In these sub areas, the application of lime with lower levels of magnesium, such as limestone predominantly enriched with calcium, increased the relatively low $\mathrm{Ca}: \mathrm{Mg}$ ratio, in order to have optimal levels of $\mathrm{Ca}$ and $\mathrm{Mg}$ in soil. Moreover, excesses in the $\mathrm{Ca}: \mathrm{Mg}$ ratio should be avoided, as it was pointed by Hernández (1995), since Ca:Mg ratio higher than 3:1 could decrease the maize growth and yield, due to antagonism of $\mathrm{Ca}$ in the absorption of $\mathrm{Mg}$ by plants.

Although liming is practiced mainly in the conventional way, application of limestone in variable rates is an actual and growing demand of farmers. In areas cultivated with sugar cane and grains, the adaptation of machines for limestone addition in a spatialized way is becoming a routine operation in different crop areas. All these facts highlights the importance of increasing the survey for data related to the spatial distribution of soil acidity attributes, in order to get precise calculation of LR in a way where soil acidity correction could be done considering the spatial distribution of soil attributes along the crop areas.

\section{CONCLUSIONS}

The variability of the soil acidity attributes and lime requirements, obtained by different methods of estimation, signal to the need of applying lime in variable rates, or to consider the existence of specifics limestone application zones, in order to reach the ideal condition of soil acidity correction for corn growth.
The precision agriculture has proved to be a viable tool to identify areas of inconsistency in terms soil acidity correction, as a consequence of the liming requirement calculation by classical methods. Precision agriculture tools also help to choose the specific limestone type to be applied in each zone of soil acidity correction.

\section{REFERENCES}

CAMBARDELLA, C.A.; MOORMAN, T.B.; NOVAK, J.M.; PARKIN, T.B.; KARLEN, D.L.; TURCO, R.F.; KONOPKA, A.E. Field-scale variability of soil properties in central Iowa soils. Soil Science Society of America Journal, Madison, v.58, p. 1501-1511, 1994.

CARVALHO, J.R.P de; SILVEIRA, P.M. da; VIEIRA, S.R. Geoestatística na determinação da variabilidade espacial de características químicas do solo sob diferentes preparos. Pesquisa Agropecuária Brasileira, v.37, p.1151-1159, 2002.

COMISSÃO DE FERTILIDADE DO SOLO DO ESTADO DE MINAS GERAIS. Recomendações para o uso de corretivos e fertilizantes em Minas Gerais. Viçosa, UFV, 1999. 359p.

CORÁ, J.E.; ARAUJO, A.V.; PEREIRA, G.T.; BERNALDO, J.M.G. Variabilidade espacial de atributos do solo para adoção do sistema de agricultura de precisão na cultura de cana-de-açúcar. Revista Brasileira de Ciência de Solo, v.28, p.10131021, 2004.

CRESSIE, N. Statistics for spatial data. New York: J. Wiley, 1991. 900p.

EMBRAPA, Embrapa Solos, Embrapa Informática Agropecuária. Manual de análises químicas de solos, plantas e fertilizantes. Brasília: Embrapa Comunicação para Transferência de Tecnologia, 1999. 370p.

FANCELLI, A.L.; DOURADO NETO, D. Milho: ecofisiología e rendimento. In: TECNOLOGIA DA PRODUÇÃO DE MILHO. Piracicaba: Trabalhos Apresentados... 1997. p.157-170.

FERREIRA, D. F. 2004. SISVAR software: versão 4.6. Lavras: DEX/UFLA, Software. 
FURTINI NETO, A.E.; VALE, F.R. do; RESENDE, A.V. de; GUILHERME, L.R.G.; GUEDES, G.A. de A. Fertilidade do solo. Lavras: UFLA/FAEPE, 2001. 252p.

HERNÁNDEZ, R. J. M. Efeito da saturação por bases, relações Ca:Mg no solo e níveis de fósforo sobre a produção de matéria seca e nutrição mineral do milho (Zea mays L.). 1995. 134p Tese (Mestrado em Agronomia)-Universidade de São Paulo, Piracicaba.

LACERDA, R. D de; MENDES, J. S.; CHAVES, L. H. Manejo de solos ácidos: comparação de métodos para avaliar a necessidade de calcário dos solos do Estado da Paraíba. Revista de Biologia e Ciências da Terra. v.6, n. 1,2006

MALAVOLTA, E.; VITTI, G. C.; OLIVEIRA, S. A. de. Avaliação do estado nutricional das plantas: princípios e aplicações. Piracicaba: POTAFOS, 1997. 319p.

MOREIRA, F.M de S.; SIQUEIRA, J.O. Microbiologia e bioquímica do solo. Lavras, 2006. 729p.

MULLA, D.J.; Mc BRATNEY, A.B. Soil spatial variability. In: SUMMER, M. E. Handbook of soil science. Boca Raton: CRC Press, 2000. A 321-352.

PADUA, T. R. P.; SILVA, C. A; DIAS, B. O. Nutrição e crescimento do algoodoeiro em latossolo sob diferentes coberturas vegetais e manejo de calagem. Ciência e Agrotecnologia, v. 32, n. 5, p. 1481-1490, set./out., 2008.

PIERCE, F.J.; WARNCKE, D.D.; EVERETT, M.W. Yield and nutrient availability in glacial soil of Michigan. In: ROBERT, P.C.; RUST, R.H.; LARSON, W.E. (Eds.). Proceedings of the Second International Conference on Site Specific Management for Agricultural Systems. Minneapolis, 1994. Madison, ASA/CSSA/SSSA, 1995. p.133-151.

PIERCE, F. J.; NOWAK, P. Aspects of precision agriculture. Advances in Agronomy, v. 67, p. 1-85, 1999.

RAIJ, B. van. Fertilidade do solo e adubação. Piracicaba: POTAFOS, 1991. 142p.

RIBEIRO Jr., P.J.; DIGGLE, P.J. (2001) geoR: A package for geostatistical analysis. R-News, v.1, n.2, ISSN 16093631. Disponível para download in http:// cran.project.org/doc/Rnews.
ROSSIELLO, R.O.P.; NETTO, J.J. Toxidez por alumínio em plantas: novos enfoques para um velho problema. In. FERNANDES, M.S. (Ed.). Nutrição mineral de plantas. SBCS: Viçosa, 2006. 375-418p.

SHOMAKER, H.E.; MCLEAN, E.O.; PRATT, P.F. Buffer methods for determining lime requirements of soils with appreciable amounts of extractable aluminum. Soil Sci. Soc. Am. Proc., v.25, p.274-277, 1961.

SILVA, V.R.; REICHERT, J.M.; STORCK, L.; FEIJÓ, S. Variabilidade espacial das características químicas do solo e produtividade de milho em um Argissolo Vermelho-Amarelo distrófico arênico. Revista Brasileira de Ciência do Solo, v.27, p.1013-1020, 2003.

SILVEIRA, P.M.; et al. Amostragem e variabilidade espacial de características químicas de um Latossolo submetido a diferentes sistemas de preparo. Pesquisa Agropecuária Brasileira, v.35, p.2057-2064, 2000.

SOUZA, L.S.; COGO, N.P.; VIEIRA, S.R. Variabilidade de propriedades físicas e químicas do solo em um pomar cítrico. Revista Brasileira de Ciência do Solo, Campinas, v.21, p.1-10, 1997.

SOUZA, Z.M. de; MARQUES JUNIOR, J.; PEREIRA, G.T.; MOREIRA, L.F. Variabilidade espacial do pH, Ca, $\mathrm{Mg}$ e V\% do solo em diferentes formas do relevo sob cultivo de cana-de-açúcar. Ciência Rural, v.34, p.17631771, 2004.

SOUZA, Z. M.; BARBIERI, D. M.; MARQUES JUNIOR, J. M.; PEREIRA, G. T.; CAMPOS, M. C. C. Influência da variabilidade de atributos químicos de um latossolo na aplicação de insumos para cultura de cana-de-açúcar. Ciência e Agrotecnologia, v. 31, p. 371-377, 2007.

VIEIRA, S.R. Geoestatística em estudo de variabilidade espacial do solo. In: NOVAIS, R.F.; ALVAREZ V., V.H.; SCHAEFER, C.E.G.R. Tópicos em ciência do solo. Viçosa, Sociedade Brasileira de Ciência do Solo, 2000, v.1, p.1-55.

VIEIRA, V. A.; MELLO, C. R.; LIMA, J. M. Variabilidade espacial de atributos físicos do solo em uma microbacia hidrográfica. Ciência e Agrotecnologia, v. 31, p. 14771485, 2007.

VIEIRA, S.R.; HATFIELD, J.L.; NIELSEN, D.R.; BIGGAR, J.W. Geoestatistical theory and application to variability of some agronomical properties. Hilgardia, v.51, p.1-75, 1983. 
VIEIRA, S.R.; PAZ-GONZALEZ, A. Analysis of the spatial variability of crop yield and soil properties in small agricultural plots. Bragantia, v.62, p.127-138, 2003.

VITTI, G. C.; TEIXEIRA, L. H. B.; BARROS JR., M. C. Diagnóstico da fertilidade do solo e adubação para alta produtividade de milho. In: FANCELLI, A. L.;

DOURADO-NETO, D. (Ed.). Milho: estratégias de manejo para alta produtividade. Piracicaba. 2003. p.174197.

WOLLENHAUPT, N.C.; MULLA, D.J.; CRAWFORD, C.A.G. Soil sampling and interpolation techniques for mapping spatial variability of soil properties. In: PIERCE, J.P.; SADLER, E.J. (Eds.). The site-specific management for agricultural systems. Madison, ASA-CSSA-SSSA, 1997. p.19-53. 